\title{
Egg inoculation of conjugated linoleic acid and lauric acid in meat quails
}

\author{
Karynne Luana Chaves de Paula ${ }^{1}\left[\right.$, Jean Kaique Valentim ${ }^{1 *} \mathbb{0}$, Sandra Regina Freitas Pinheiro ${ }^{1}[$, \\ Diana Maryuri Correa Castiblanco ${ }^{1} \mathbb{\infty}$, Andressa Silva Santos ${ }^{1} \oplus{ }^{\oplus}$, Gabriel Machado Dallago ${ }^{1} \oplus$, \\ Diogo Alvarenga Miranda ${ }^{1}$, Felipe Santos Dalólio ${ }^{1}[0$
}

\footnotetext{
1 Universidade Federal dos Vales do Jequitinhonha e Mucuri, Diamantina, MG, Brasil. E-mail: karynne.luana@hotmail.com; kaique.tim@hotmail.com; sandrafreitaspinheiro@gmail.com; diana.castilho@gmail.com; andressa.santos@gmail.com; gabrieldallago@gmail.com; diogo.alvarenga92@gmail.com; felipe.santos@hotmail.com
}

ABSTRACT: The objective of this study was to evaluate the effects of inoculation in egg with sources of conjugated linoleic acid (CLA) and lauric acid (LA) on hatchability, zootechnical performance and carcass characteristics of quails from one to 35 days of age. On the $7^{\text {th }}$ day of incubation, the eggs were inoculated with $0.05 \mathrm{~mL}$ of the supplement according to the treatments, CLA and LA. After birth, the birds were housed in cages until 35 days. A completely randomized design was used, with six treatments and six replicates of 10 birds per cage. The inoculations in eggs with CLA and LA did not interfere in the performance and carcass characteristics of quails at 21 and 35 days of age. However, may be associated with a decrease in egg hatchability. The highest absolute weight of the gizzard was observed at 35 days, from birds inoculated in egg with CLA $240 \mathrm{mg}$ and LA $60 \mathrm{mg}$ in the incubation phase, in comparison to the other treatments. In conclusion, the reduction in hatchability makes it impossible to recommend the use of conjugated linoleic acid and lauric acid - in ovo.

Key words: fatty acid; immunity; in ovo nutrition; quail production

\section{Inoculação de ácido linoléico conjugado e ácido láurico}

\section{in ovo em codornas de corte}

RESUMO: O objetivo deste trabalho foi avaliar os efeitos da inoculação in ovo com fontes de ácido linoléico conjugado (CLA) e ácido láurico (LA) sobre a eclodibilidade, desempenho zootécnico e características de carcaça de codornas de um a 35 dias de idade. No $7^{\circ}$ dia de incubação, os ovos foram inoculados com $0,05 \mathrm{~mL}$ do suplemento de acordo com os tratamentos. Após o nascimento, as aves foram alojadas em gaiolas por até 35 dias. 0 delineamento experimental utilizado foi inteiramente ao acaso, com seis tratamentos e seis repetições de 10 aves por gaiola. Inoculações em ovos com CLA e LA não interferiram no desempenho e nas características de carcaça de codornas aos 21 e 35 dias de idade. Entretanto, está associado à diminuição da eclodibilidade dos ovos. 0 maior peso absoluto da moela foi observado aos 35 dias, nas aves inoculadas em ovo com CLA 240 mg e LA $60 \mathrm{mg}$ na fase de incubação, em comparação aos demais tratamentos. Em conclusão, a redução da eclodibilidade impossibilita recomendar o uso de ácido linoléico conjugado e ácido láurico - in ovo.

Palavras-chave: ácidos graxos; imunidade; nutrição in ovo; produção de codornas

\footnotetext{
* Jean Kaique Valentim - E-mail: kaique.tim@hotmail.com (Corresponding author)

Associate Editor: Edney Pereira da Silva
} 


\section{Introduction}

Scientific studies that address the incubation phases, the embryonic development of the chicks that precede the life after hatching, are scarce and are necessary to obtain better zootechnical indexes of poultry plants. In egg vaccination was already a reality more than ten years ago and has now become an early management tool in incubators (Jha et al., 2019) allowing future immunization of chicks with no impact on embryo development or hatching rate.

Based on this principle, in egg substance management technology gained prominence along with nutritional management, that is, in egg nutrition. In general, the procedure is done by drilling the shell of the embryonated egg and inoculating the nutrient in the internal content of the egg by means of a syringe (Alsultan et al., 2020). Understanding the stage of embryo development and the incubation time most conducive to egg injection are the key issues that must be studied to maximize hatchability and chick quality after hatching. Nasir \& Peebles (2018) report that the location and date of inoculation in egg affect hatching; therefore, to segment preferred sites within the embryonated egg, one needs to understand the different physiological characteristics associated with the embryonic development phase.

All these needs are crucial for the early supplementation of nutrients in the prehatching phase to achieve the goal of being a nutritional management tool that provides better conditions for the initial development of the gastrointestinal system and thus accelerate the enzymatic activities (Refaie, 2018), with the aim of favouring productive economic viability. Associated with this, it is possible to explore early nutrition through the immunonutrition (Alves et al., 2020) approach that seeks to modulate responses, not only to favour post hatch performance, but also to prepare the animal for the health challenges that productive systems entail.

Conjugated linoleic acid (CLA) is associated with an increase in the efficiency of the immune system, being an important anticancer, rendering the animal less susceptible to diseases and consequently diverting less energy from the production to the maintenance of immune defences (Mehr et al., 2014). Lauric acid (LA) is a potent antibiotic, credited by many with strong suppression not only of bacterial infections, but also of fungal and viral infections (Shokraneh et al., 2020).

The objective of this study was to evaluate the effects of inoculation in egg with two sources of fatty acids, one for conjugated linoleic acid and the other for lauric acid on eggs hatchability, zootechnical performance and carcass characteristics meat-type quails from 1 to 35 days of age.

\section{Materials and Methods}

The experiment was carried out in the Incubator and in the Laboratory of Monogastric Animal Research, both belonging to the Animal Science Department of the Universidade Federal dos Vales do Jequitinhonha e Mucuri, from July to September 2018. The research was approved by the Commission of Ethics in the Use of Animals (CEUA) of the Universidade Federal dos Vales do Jequitinhonha e Mucuri, with protocol no. 026/2017. The experimental periods consisted of the incubation phase, with duration of 18 days and growth phase of the birds, which were evaluated from 1 to 21 and 22 to 35 days of age.

Were incubated 839 fertile quail eggs, were obtained from the 29-week-old batch of European lineage of the "Fujikura quail farm", located in Suzano, SP - Brazil. The individual weight of each egg was computed to calculate the yield of quail chick. Utilized an incubator of the brand COPEMARQ, model Labo 13, previously disinfected and equipped with automatic control of temperature, humidity and turning of the eggs. For CLA supplementation, the product Lipo-6 CLA, commercial brand Nutrex Research, with a concentration of $1000 \mathrm{mg}$ was used, and for the supplementation of LA, extra virgin coconut oil of commercial origin was used, with the packaging of 200 $\mathrm{mL}$, belonging to the brand Copra Coco.

For the composition of the treatments with the supplements of fatty acids, the commercial oils were weighed in the proportions and diluted in $50 \mathrm{~mL}$ with the diluent (corn oil). The experimental treatments were the follows: Control: control group, without inoculation; $\mathrm{CO}$ : eggs inoculated with diluent: corn oil; CLA120: eggs inoculated with CLA $120 \mathrm{mg}$ $50 \mathrm{~mL}^{-1}$ corn oil; CLA240: eggs inoculated with CLA $240 \mathrm{mg} 50$

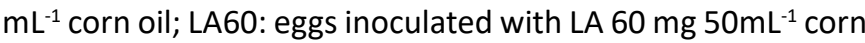
oil and LA90: eggs inoculated with LA $90 \mathrm{mg} 50 \mathrm{~mL}^{-1}$ corn oil.

On the $7^{\text {th }}$ day of incubation, the eggs were inoculated with the experimental treatments. After disinfection of the ethanol injection site, the eggs were punctured and then injected with $0.05 \mathrm{~mL}$ of the supplement using $1 \mathrm{~mL}$ disposable syringes in the albumin region approximately $3 \mathrm{~mm}$ below the shell. The duration of the inoculation procedure for each treatment was approximately 40 minutes, thus, to ensure that all treatments were subjected to the same period of time outside the incubator.

The intact eggs that composed the control treatment were also removed from the machine and exposed to the same environment to standardize withdrawal of the incubator in all treatments. At the day 15 of incubation all eggs were the transferred to the hatchers where they remained until hatching, for another 2 or 3 days.

At birth, the selected birds were housed in galvanized wire cages, containing feeders and drinking and 100-watt incandescent lamps for heating birds. In this phase, 360 quails were used in a completely randomized design, in six treatments, with six replicates of ten quails per plot, applying the same treatments defined in the incubation phase. After birth, the quails were fed the same diets in the initial and growth phases, in order to verify the effects of in ovo inoculation.

The rations were elaborated based on conventional diets for the specie, meeting the nutritional requirements recommended by Silva \& Costa (2009), both for the initial phase ( 1 to 21 days) and for the growth stage (22 to 35 days) according to Table 1. 
Table 1. Composition of diet in initial and growth phases.

\begin{tabular}{|c|c|c|}
\hline Ingredients (\%) & 1 to 21 days & 22 to 35 days \\
\hline Corn & 49.6157 & 54.8315 \\
\hline Soybean meal & 42.8111 & 38.4348 \\
\hline Soybean oil & 3.0763 & 4.0230 \\
\hline Limestone & 1.2768 & 1.0579 \\
\hline Dicalcium phosphate & 1.0318 & 0.7937 \\
\hline Sodium chloride & 0.3748 & 0.3232 \\
\hline Min+Vit premix ${ }^{1}$ & 0.1000 & 0.1000 \\
\hline L-lysine $\mathrm{HCl}$ & 0.2340 & 0.0000 \\
\hline L-valine & 0.0162 & 0.0000 \\
\hline L-isoleucine & 0.3212 & 0.1637 \\
\hline DL-methionine & 0.4228 & 0.2131 \\
\hline L-threonine & 0.2740 & 0.0490 \\
\hline Antioxidant ${ }^{2}$ & 0.0100 & 0.0100 \\
\hline Total & 100.00 & 100.00 \\
\hline \multicolumn{3}{|c|}{ Calculated composition } \\
\hline Metabolizable energy (Kcal/Kg) & 2.900 & 3.000 \\
\hline Calcium (\%) & 0.85 & 0.70 \\
\hline Nonphytate P (\%) & 0.32 & 0.27 \\
\hline Sodium (\%) & 0.18 & 0.16 \\
\hline Crude protein (\%) & 25.00 & 22.00 \\
\hline Digestible arginine (\%) & 1.92 & 1.52 \\
\hline Digestible isoleucine (\%) & 1.14 & 0.9 \\
\hline Digestible lysine (\%) & 1.37 & 1.08 \\
\hline Digestible metionine + cystine (\%) & 1.05 & 0.81 \\
\hline Digestible threonine (\%) & 1.04 & 0.78 \\
\hline Digestible tryptophan (\%) & 0.27 & 0.24 \\
\hline Digestible valine (\%) & 1.01 & 0.92 \\
\hline
\end{tabular}

As a form of sanitary challenge to stimulate the immune system, it was adopted not to regularly clean the drinking fountains and the floor of the cages (lined with newspaper) and the lack of execution of the schedule of vaccines indicated for the species.

The performance variables evaluated were feed intake (FI), weight gain (WG) and feed conversion (FC). Mortality was monitored daily for the correction of intake and feed conversion, considering the day of bird death in relation to the period of the stage. At 35 days of age, two birds were taken from each experimental unit to evaluate the carcass yield and the absolute weight of the organs of interest in the research. The birds were identified, weighed individually and the submission fasted for six hours without food.

Soon after, the cuts and the weighing's were slaughtered, plucked, eviscerated and effected. The parameters evaluated were the live weight $(\mathrm{g})$, the weight of noble cuts (breast and thigh + drumstick) and the weight of metabolically active organs, gizzard and heart, all expressed in absolute weight.

The results were analysed through the program $R$ ( $R$ Core Team, 2017) at the level of $5 \%$ significance. To verify the normal distribution of errors, the Shapiro-Wilk normality test was applied. The homoscedasticity was evaluated by the Bartlett test and the independence of the errors was evaluated by the Durbin-Watson test. The nonparametric Kruskal-Wallis test was used for variables that did not satisfy the assumptions.

For performance and carcass characteristics the data were subjected to analysis of variance (ANOVA) between the treatments, as well as the orthogonal contrasts to compare the results obtained among the birds that received the control treatments with each of the levels of supplementation of the tested fatty acids (CLA and LA) inoculated in eggs. For the hatchability percentage of eggs, the Chi-Square test was applied at the level of $5 \%$.

\section{Results}

Egg weight and chick weight did not obtain statistical differences ( $p>0.05$ ) according to Table 2 .

The eggs hatched between the $17^{\text {th }}$ and $18^{\text {th }}$ day of incubation. Hatchability results showed, in a descriptive way (Figure 1), that there was a higher embryonic mortality in eggs inoculated with CLA and LA, and the CLA inoculations provided a higher death rate in comparison to the LA.

In egg supplementation with CLA and LA did not show any influence $(p>0.05)$ on the results of zootechnical performance in the 1 to 21 days phase, as well as for the growth phase (Table 3).

The body weight and the weights of the cuts (breast and thigh + drumstick) were observed at 35 days of age and did

Table 2. Means and standard deviations for egg weight, chick weight at birth and chick yield of meat quails supplemented in egg with sources of conjugated linoleic acid and lauric acid.

\begin{tabular}{lccc}
\hline \multicolumn{4}{c}{ Parameters } \\
\hline Treatments & $\begin{array}{c}\text { Egg } \\
\text { weight (g) }\end{array}$ & $\begin{array}{c}\text { Weight } \\
\text { of the chick (g) }\end{array}$ & $\begin{array}{c}\text { Chick } \\
\text { yield (\%) }\end{array}$ \\
\hline Control & $14.85 \pm 0.96$ & $10.11 \pm 0.92$ & 68.08 \\
CO & $14.58 \pm 1.10$ & $10.12 \pm 0.75$ & 69.41 \\
CLA 120 mg & $14.72 \pm 1.04$ & $10.26 \pm 0.80$ & 69.70 \\
CLA 240 mg & $15.04 \pm 1.07$ & $10.24 \pm 0.87$ & 68.09 \\
LA 60 mg & $14.88 \pm 1.04$ & $10.19 \pm 0.89$ & 68.48 \\
LA 90 mg & $14.68 \pm 1.20$ & $10.11 \pm 0.97$ & 68.87 \\
p Value & 0.4182 & 0.9168 & 0.102 \\
CV (\%) & 7.35 & 8.71 & 9.73 \\
\hline
\end{tabular}

CO: Corn oil; CLA: Conjugated linoleic acid; LA: Lauric acid; CV: Coefficient of variation (\%).

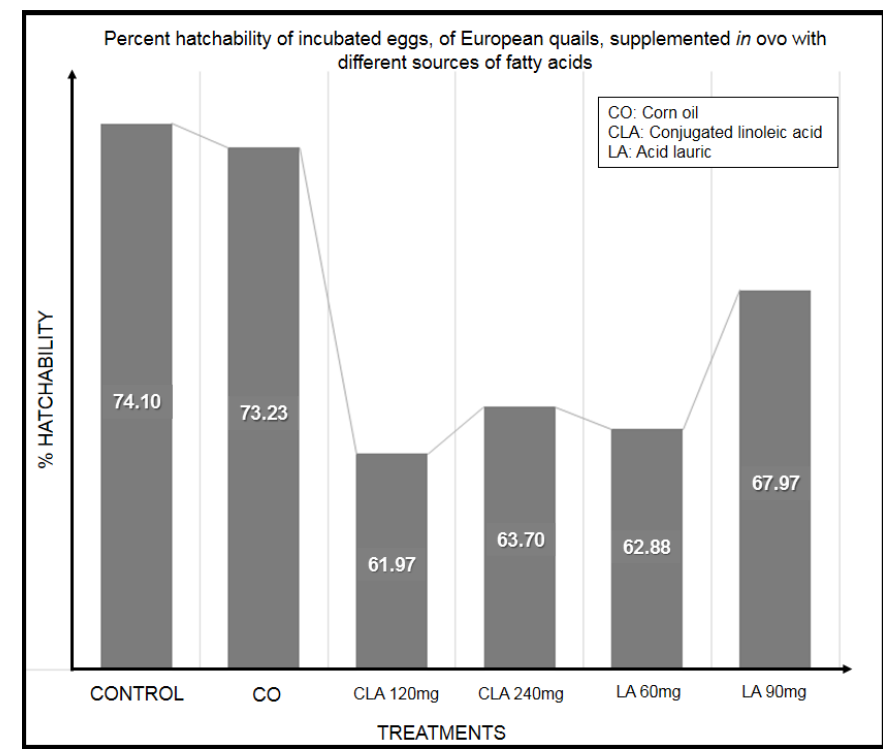

Figure 1. Percent hatchability of incubated eggs, of meat quails, supplemented CLA and LA. 
Table 3. Feed intake (FI), weight gain (WG) and feed conversion (FC), of meat quails supplemented in egg with sources of CLA and LA.

\begin{tabular}{|c|c|c|c|c|c|c|}
\hline \multirow{2}{*}{ Treatments } & \multicolumn{3}{|c|}{21 days age } & \multicolumn{3}{|c|}{35 days age } \\
\hline & FI (g bird $\left.{ }^{-1}\right)$ & WG (g bird ${ }^{-1}$ ) & $\mathrm{FC}\left(\mathrm{g} \mathrm{g}^{-1}\right)$ & $\mathrm{FI}\left(\mathrm{g} \mathrm{bird}^{-1}\right)$ & WG (g bird ${ }^{-1}$ ) & $F C\left(g^{-1}\right)$ \\
\hline Control & 226.14 & 122.60 & 1.84 & 318.51 & 90.19 & 3.54 \\
\hline $\mathrm{CO}$ & 232.45 & 122.68 & 1.89 & 311.38 & 87.39 & 3.56 \\
\hline CLA $120 \mathrm{mg}$ & 234.15 & 126.83 & 1.84 & 326.39 & 91.18 & 3.58 \\
\hline CLA $240 \mathrm{mg}$ & 221.10 & 120.74 & 1.83 & 328.08 & 93.14 & 3.52 \\
\hline LA $60 \mathrm{mg}$ & 220.43 & 124.73 & 1.76 & 333.77 & 96.06 & 3.47 \\
\hline CV (\%) & 5.84 & 4.69 & 4.22 & 4.84 & 6.46 & 6.21 \\
\hline
\end{tabular}

CO: Corn oil; CLA: Conjugated linoleic acid; LA: Lauric acid; CV: Coefficient of variation (\%).

Table 4. Means and standard deviations for body weight (BW), weight breast (WB), weight thigh (WT), heart and gizzard of meat quails supplemented in egg with sources of CLA and LA at 35 days old.

\begin{tabular}{lccccc}
\hline \multirow{2}{*}{ Treatments } & \multicolumn{5}{c}{ Parameters } \\
\cline { 2 - 6 } & BW $(\mathbf{g})$ & WB $(\mathbf{g})$ & WT $(\mathbf{g})$ & Heart $(\mathbf{g})$ & Gizzard $(\mathbf{g})$ \\
\hline Control & $229.16 \pm 13.45$ & $61.83 \pm 4.13$ & $38.33 \pm 2.13$ & $1.77 \pm 0.28$ & $4.13 \pm 0.21^{*}$ \\
CO & $227.33 \pm 4.17$ & $61.16 \pm 0.98$ & $37.75 \pm 1.36$ & $1.75 \pm 0.22$ & $4.40 \pm 0.25$ \\
CLA $120 \mathrm{mg}$ & $229.91 \pm 9.47$ & $60.50 \pm 1.76$ & $39.33 \pm 1.36$ & $1.74 \pm 0.12$ & $4.13 \pm 0.21$ \\
CLA 240 mg & $230.83 \pm 9.55$ & $61.16 \pm 1.96$ & $39.08 \pm 2.49$ & $1.89 \pm 0.17$ & $4.69 \pm 0.44^{*}$ \\
LA 60 mg & $242.25 \pm 6.97$ & $67.66 \pm 4.72$ & $41.08 \pm 2.51$ & $1.93 \pm 0.28$ & $4.75 \pm 0.33^{*}$ \\
LA 90 mg & $228.33 \pm 9.02$ & $60.58 \pm 3.98$ & $38.00 \pm 2.96$ & $1.81 \pm 0.29$ & $4.51 \pm 0.58$ \\
P Value & 0.08 & 0.09 & 0.14 & 0.67 & 0.02 \\
CV (\%) & 3.98 & 2.01 & 5.71 & 13.17 & 8.27 \\
\hline
\end{tabular}

CO: Corn oil; CLA: Conjugated linoleic acid; LA: Lauric acid; CV: Coefficient of variation (\%).

not present differences ( $p>0.05$ ) with the exception of the gizzard significant difference $(p<0.05)$, according to Table 4.

The organs of metabolic function, gizzard and heart, were evaluated at 35 days of age. The mean heart weight had no significant difference $(p>0.05)$ compared to the treatments studied. However, for the weight of the gizzard a significant difference $(p<0.05$ ) was observed in intact eggs (control treatment) in relation to the inoculation with CLA $240 \mathrm{mg}$ and LA $60 \mathrm{mg}$ (Table 4). The birds supplemented in egg with LA 60 $\mathrm{mg}$ and CLA $240 \mathrm{mg}$ obtained higher mean weight (4.75 and $4.69 \mathrm{~g}$, respectively) of the gizzard in comparison with those that did not receive inoculations (4.13 g).

\section{Discussion}

According to the results of hatchability, it was observed that higher embryonic mortality occurred with eggs inoculated with CLA and LA, and inoculations with CLA provided higher mortality in relation to LA. According to the results of hatchability, it was observed that higher embryonic mortality occurred with eggs inoculated with CLA and LA, and inoculations with CLA provided higher mortality in relation to LA. Possibly there were changes in the content of saturated and unsaturated fatty acids in eggs, making it impossible to fully use embryos, resulting in energy deficit.

Alaqil et al. (2020) added different levels of CLA in the matrix diet and reported embryonic deaths in quail eggs during incubation, and justified that such consequences would be related to the alteration of the relationship between saturated and unsaturated fatty acids within the egg. During this stage, the yolk sac provides liposoluble vitamins, essential fatty acids and phospholipids to the embryos and are used for tissue formation, as well as being the only energetic source available. Therefore, changes in the yolk sac contents may have a direct influence on the developing embryo (Alves et al., 2020).

Once the homogenization management of incubated eggs is adopted, it is naturally expected that the egg weight will not show significant changes, but the supplementation of the oils could affect the weight of the chick at birth, as already recorded in a previous study conducted by Damasceno et al (2017), this fact not observed in the present study (Table 2).

The weight of the quail, mainly at the beginning of production, will influence the size of the egg, which is on average 11 and $14 \mathrm{~g}$ the Japanese and European strains, respectively, and the weight of the chick at hatching has a direct relationship with the weight of the egg, corresponding to 62 to $76 \%$ of this weight (Hanafy \& Hegab, 2019).

The chick yield of quails among the treatments studied (Table 2 ) presented a general average of $68.77 \%$, being within the recommended for the species, as discussed by Hanafy $\&$ Hegab (2019).

This result showed in the Table 2 , that a possible negative interference in hatchability percentage (below 70\%) is related to the inoculation of different levels, rather than the application of the in-egg nutrition technique. Even with the fall in hatchability between treatments that received CLA and LA inoculations, it is worth mentioning that similar results for percentage of birth of meat-type quails were described by other authors, with or without supplementation in eggs (Carneiro et al., 2014; Araújo et al., 2015). 
In addition to the fact that there were no significant differences between inoculated treatments compared to whole eggs, observed in Table 3, in general all the groups obtained zootechnical indexes within the recommended for the specie and according to Silva et al. (2012). The similarities in the mean values of the $\mathrm{FI}, \mathrm{WG}$ and $\mathrm{FC}$ variables can be explained due to a low sanitary challenge in the quail rearing environment. According Den Hartigh et al. (2018) the evidence for the influence of CLA on body weight is explicit, in which the effects of CLA on body fat reduction occur in the differentiation phase of adipocytes due to the decrease in the size of these cells. However, the same effect of in egg supplementation on productive performance was not found in this research (Table 3).

When evaluating the inoculation of CLA in broiler eggs, Mehr et al. (2014) observed an increase in feed intake and weight gain of birds from 1 to 42 days of age CLA was injected into the air sack of the selected eggs (150 and 300 $\mathrm{mg}$, dissolved in $100 \mathrm{~mL}$ of commercial diluents, CLA150 and CLA300) on day 18 of incubation. The authors verified better results for feed conversion of birds that received higher levels of CLA300 compared to birds that did not receive inoculations, or inoculations with diluent and CLA150.

Sources of oils (soybean, linseed and sardine) and their relevance in the performance and immunity of broiler chickens were studied by Pinto et al. (2014) and as in this research, even though in a different way than the supplementary one, the authors verified that the type of oil added in the broiler diet did not influence the performance variables, such as weight gain and final weight.

Working with broilers in the final stage ( 22 to 35 days of age), Ko et al. (2004) provided three experimental diets with different combinations $(1.5 \% \mathrm{CO}, 0.75 \%$ CO plus $0.75 \%$ CLA, and $1.5 \% \mathrm{CLA})$, all of which are isoenergetic, and did not observe a difference in the weight gain of the animals.

However, it can be stated that the effects of CLA and LA on bird performance depend on several factors such as levels of insertion, specie and management adopted. It is noticeable that the literature information currently available on the use of CLA and LA in poultry nutrition is based on research carried out on chickens and laying hens, which, in comparison to quails, has an extremely higher commercial visibility.

The reason for this may be linked to the market, which encourages the production of foods rich in nutrients, such as eggs enriched with CLA, mainly, but also the delivery of a meat with profiles of fatty acids beneficial to the health of the consumer. In this respect, the creation of quails is in great growth, both for meat production and for eggs, which justifies the development of research in the area.

However, Zeitz et al. (2015) reported that diets rich in lauric acid and myristic acid provided higher breast weight in broiler chickens compared to the control group, without supplementation of fatty acids, what was not observed in this research.

In our study we observed that the weight of gizzard at 35 days of age increased with the inoculations of CLA 240 and
LA 60 in relation to birds that did not receive inoculations with fatty acids in the eggs. The structure of the gizzard is connected directly to the food consumed by the bird and the optimization in the use of it, after all, this organ influences the feed consumption by the particle reduction.

Therefore, greater weight of gizzard indicates a greater capacity for maceration and effective mixing of the food bolus with the mucus that will contribute to the subsequent digestive processes. Thus, this greater development of the gizzard could provide better performance by the best assimilation of the nutrients present in the ration. However, we did not observe an effect for the $\mathrm{Fl}$ of the quails.

In an as-hatched of meat quails, Veras (2017), found a significant effect for the weight of the gizzard at 45 days of age with the inclusion of $2 \%$ of canola oil and $2 \%$ of coconut oil, presenting lower absolute weight (3.72 and $3.42 \mathrm{~g}$, respectively) compared to the mean values verified in the present study, where all means were above the values found by the author.

The literature is inefficient to clearly support the observed data behaviour, especially on the use of lauric acid. On the other hand, Silvério (2016) found that day-old chicks from cutting matrices receiving CLA $(0.023 \%$ in the diet) presented higher absolute weights of compared to not supplementing this fatty acid. Different levels of those evaluated in this research should be explored to verify the influence of CLA and LA on carcass performance and characteristics through in egg nutrition. Several factors may interfere with the success of the in-egg nutrition technique and need to be explored, such as which nutrient to be supplemented, the dosage thereof, the site of inoculation in the egg, and the ideal age for inoculation of the eggs.

\section{Conclusion}

The reduction in hatchability makes it impossible to recommend the use of conjugated linoleic acid and lauric acid in ovo injection.

\section{Acknowledgements}

This study was financed in part by the Coordenação de Aperfeiçoamento de Pessoal de Nível Superior - Brasil (CAPES) Finance Code 001.

\section{Compliance with Ethical Standards}

Author contributions: Conceptualization: KLCP, SRFP; Formal analysis; GMD; Investigation: KLCP, SRFP, DMCC; Methodology: KLCP, JKV, ASS, DAM, FSD; Project administration: KLCP, SRFP; Resources: KLCP, JKV, ASS, DAM, FSD; Supervision: DMCC, SRFP, FSD; Validation: DMCC, SRFP, FSD; Visualization: DMCC, SRFP, FSD; Writing - original draft: KLCP, SRFP, JKV; Writing - review \& editing: KLCP, SRFP, JKV.

Conflict of interest: The authors declared that there is no possible conflict of interest (professional or financial) that may influence the article. 
Financing source: Coordenação de Aperfeiçoamento de Pessoal de Nível Superior - Brasil (CAPES) - Finance Code 001 and Universidade Federal dos Vales do Jequitinhonha e Mucuri.

\section{Literature Cited}

Alaqil, A. A.; Abbas, A. O.; El-Beltagi, H. S.; El-Atty, H.; Abd, K.; Mehaisen, G. M.; Moustafa, E. S. Dietary supplementation of probiotic lactobacillus acidophilus modulates cholesterol levels, immune response, and productive performance of laying hens. Animals, v. 10, n. 9, e1588, 2020. https://doi.org/10.3390/ani10091588.

Alsultan, O. M.; Al-Khafaji, F. R. A.; Gmash, H. N. Effects of combining in ovo injection by nutritive solutions and early post-hatch nutrition on productive performance of broiler. Plant Archives, v. 20, suppl. 2, p.1584-1591, 2020. http://www.plantarchives.org/ SPL\%20ISSUE\%2020-2/261_1584-1591_.pdf. 06 Sep. 2020.

Alves, L. K. S; Viana, G. P; Santos, T. S; Reis, B. Q.; Buck, E.; Nacimento, R. A; Ranieri, C.; Araújo, C. S. da S. In-ovo feeding: a review. Veterinária Notícias, v. 26, n. 1, p. 50-67, 2020. https:// doi.org/10.14393/VTN-v26n1-2020-51611.

Araújo, I. C. S. D.; Mesquita, M. A.; Andrade, M. A.; Castejon, F. V.; Café, M. B.; Arnhold, E.; Leandro, N. S. M. Efeito do período e temperatura de armazenamento de ovos férteis sobre o rendimento de incubação e características de qualidade de codornas neonatas. Arquivo Brasileiro de Medicina Veterinária e Zootecnia, v. 67, n. 6, p. $1693-1702,2015$. https://doi. org/10.1590/1678-4162-8012.

Carneiro, T. C; Santos, T.C.; Murakami, A. E.; Rossi, R. M.; Fanhani, J. C. Stefanello, C. Influência da idade dos reprodutores de codornas de postura na reprodução, na qualidade de ovos e na morfologia dos órgãos genitais. Semina: Ciências Agrárias, v. 35 , n. 5 , p. $2449-2465$, 2014. https://doi.org/10.5433/16790359.2014v35n5p2449.

Damasceno, J. L.; Cruz, F. G. G.; Melo, R. D.; Feijo, J. C.; Rufino, J. P. F.; Valentim, F. M.; Oliveira, J. P. C. Inoculação de proteína isolada de soja em ovos embrionados oriundos de matrizes semipesadas com diferentes idades. Arquivo Brasileiro de Medicina Veterinária e Zootecnia, v. 69, n. 5, p. 1259-1266, 2017. https://doi.org/10.1590/1678-4162-9069.

Den Hartigh, L. J.; Gao, Z.; Goodspeed, L.; Wang, S.; Das, A. K.; Burant, C. F.; Chait, A.; Blaser, M. J. Obese mice losing weight due to trans-10, cis-12 conjugated linoleic acid supplementation or food restriction harbor distinct gut microbiota. The Journal of nutrition, v. 148, n. 4, p. 562-572, 2018. https://doi.org/10.1093/ jn/nxy011.

Hanafy, A. M.; Hegab, I. M. Effects of egg weight and light sources during incubation period on embryonic development and posthatch growth of Japanese quail (Coturnix japonica). European Poultry Science, v. 83, e268, 2019. https://doi.org/10.1399/ eps.2019.268.

Jha, R.; Singh, A. K.; Yadav, S.; Berrocoso, J. F. D.; Mishra, B. Early nutrition programming (in ovo and post-hatch feeding) as a strategy to modulate gut health of poultry. Frontiers in Veterinary Science, v. 6, e82, 2019. https://doi.org/10.3389/ fvets.2019.00082.
Ko, Y. H.; Yang, H. Y.; Jang, I. S. Effect of conjugated linoleic acid on intestinal and hepatic antioxidant enzyme activity and lipid peroxidation in broiler chickens. Asian-Australasian Journal of Animal Sciences, v. 17, n. 8, p. 1162-1167, 2004. https://doi. org/10.5713/ajas.2004.1162.

Mehr, M. A.; Hassanabadi, A.; Mirghelenj, S. A.; Kermanshasi, $H$. Effects of in ovo injection of conjugated linoleic acid on immune status and blood biochemical factors of broiler chickens. Spanish Journal of Agricultural Research, n. 2, p. 455-461, 2014. https:// dialnet.unirioja.es/servlet/articulo?codigo $=4861535$. 11 Sep. 2020.

Nasir, Z.; Peebles, E. D. Symposium: avian embryo nutrition and incubation. Poultry Science, v. 97, n. 8, p. 2994-2995, 2018. https://doi.org/10.3382/ps/pey137.

Pinto, M. F.; Lima, V. M.; Ribeiro, S. C.; Bossolani, I. L.; Ponsano, E. H.; Garcia-Neto, M. Fontes de óleo na dieta e sua influência no desempenho e na imunidade de frangos de corte. Pesquisa Veterinária Brasileira, v. 34, n. 5, p. 409-414, 2014. https://doi. org/10.1590/S0100-736X2014000500004.

R Core Team. R. A language and environment for statistical computing. Version 3.5.2 "Eggshell Igloo". Vienna: R Foundation for Statistical Computing, 2017.

Refaie, A. M. In-ovo feeding and early nutrition by glucose and their effects in improving hatchability and performance of fayoumi chicks. Egyptian Poultry Science Journal, v. 38, n. 2, p. 497-511, 2018. https://epsj.journals.ekb.eg/article_8274.html. 01 Sep. 2020.

Shokraneh, M.; Sadeghi, A. A.; Mousavi, S. N.; Esmaeilkhanian, S.; Chamani, M. Effects of in ovo injection of nano-selenium and nano-zinc oxide and high eggshell temperature during late incubation on antioxidant activity, thyroid and glucocorticoid hormones and some blood metabolites in broiler hatchlings. Acta Scientiarum. Animal Sciences, v. 42, n.1, e46029, 2020. https:// doi.org/10.4025/actascianimsci.v42i1.46029.

Silva, J. H. V.; Costa, F. G. P. Tabela para codornas japonesas e europeias. Jaboticabal: Funep, 2009. 110p.

Silva, J. H. V.; Jordão Filho, J.; Costa, F. G. P.; Lacerda, P. B.; Vargas, D. G. V.; Lima, M. R. Exigências nutricionais de codornas. Revista Brasileira de Saúde e Produção Animal, v. 13, n. 3, p.775-790 2012. https://doi.org/10.1590/S1519-99402012000300016.

Silvério, P. S. Inclusão do CLA na dieta de matrizes de corte e tempos de armazenamento de ovos incubáveis sobre o rendimento da incubação e qualidade da progênie. Brasília: Universidade de Brasília, 2016. 98p. Master Thesis. https://repositorio.unb.br/ handle/10482/22136. 25 Aug. 2020.

Veras, A. G. Rações enriquecidas com óleo de coco e óleo de canola no desempenho e perfil lipídico da carne de codornas europeias. Natal: Universidade Federal do Rio Grande do Norte, 2017. 64 p. Master Thesis. https://repositorio.ufrn.br/ handle/123456789/24474. 27 Aug. 2020.

Zeitz, J. O.; Fennhoff, J.; Kluge, H.; Stangl, G. I.; Eder, K. Effects of dietary fats rich in lauric and myristic acid on performance, intestinal morphology, gut microbes, and meat quality in broilers. Poultry Science, v. 94, n. 10, p. 2404-2413, 2015. https:// doi.org/10.3382/ps/pev191. 